\title{
Nitrogen transfer from forage legumes to nine neighbouring plants in a multi-species grassland
}

\author{
Karin Pirhofer-Walzl • Jim Rasmussen • \\ Henning Hogh-Jensen • Jørgen Eriksen • \\ Karen Søegaard • Jesper Rasmussen
}

Received: 31 March 2011 /Accepted: 21 June 2011 / Published online: 6 July 2011

(C) Springer Science+Business Media B.V. 2011

\begin{abstract}
Legumes play a crucial role in nitrogen supply to grass-legume mixtures for ruminant fodder. To quantify $\mathrm{N}$ transfer from legumes to neighbouring plants in multi-species grasslands we established a grass-legume-herb mixture on a loamy-sandy site in Denmark. White clover (Trifolium repens L.), red clover (Trifolium pratense L.) and lucerne (Medicago sativa L.) were leaf-labelled with ${ }^{15} \mathrm{~N}$ enriched urea during one growing season. $\mathrm{N}$ transfer to grasses (Lolium perenne L. and xfestulolium), white clover, red clover, lucerne, birdsfoot trefoil (Lotus corniculatus L.), chicory (Cichorium intybus L.), plantain (Plantago lanceolata L.), salad burnet (Sanguisorba minor L.) and caraway (Carum carvi L.) was assessed. Neigh-
\end{abstract}

Responsible Editor: Katja Klumpp.

K. Pirhofer-Walzl $(\bowtie) \cdot J$. Rasmussen

Department of Agriculture and Ecology,

Faculty of Life Sciences, University of Copenhagen,

Højbakkegaard Allé 9,

2630 Taastrup, Denmark

e-mail: karin.pirhofer@gmail.com

J. Rasmussen · J. Eriksen · K. Søegaard

Department of Agroecology and Environment,

Faculty of Agricultural Sciences, Aarhus University,

Blichers Allé 20,

8830 Tjele, Denmark

\section{H. Høgh-Jensen}

Faculty of Science and Technology,

Department of Policy Analysis, Aarhus University,

Frederiksborgvej 399,

4000 Roskilde, Denmark bouring plants contained greater amounts of $\mathrm{N}$ derived from white clover $\left(4.8 \mathrm{gm}^{-2}\right)$ compared with red clover $\left(2.2 \mathrm{gm}^{-2}\right)$ and lucerne $\left(1.1 \mathrm{gm}^{-2}\right)$. Grasses having fibrous roots received greater amounts of $\mathrm{N}$ from legumes than dicotyledonous plants which generally have taproots. Slurry application mainly increased N transfer from legumes to grasses. During the growing season the three legumes transferred approximately $40 \mathrm{~kg} \mathrm{~N} \mathrm{ha}^{-1}$ to neighbouring plants. Below-ground $\mathrm{N}$ transfer from legumes to neighbouring plants differed among nitrogen donors and nitrogen receivers and may depend on root characteristics and regrowth strategies of plant species in the multi-species grassland.

Keywords ${ }^{15} \mathrm{~N}$ transfer. Grass-legume-herb grassland - Root characteristics - Trifolium repens L. . Trifolium pratense L. Medicago sativa $\mathrm{L}$.

\section{Introduction}

Leguminosae is a cosmopolitan plant family that feeds a large part of the world (Lewis et al. 2005). Trifolium and Medicago are the two key genera used for forage production in temperate grassland based farming systems (Frame 2005). Since the Romans legumes have been used in grasslands and for soil improvement (Fred et al. 1932). With easy access to mineral fertilizer grass monocultures were widely adopted in the second half of the 20th century. Today, however, more sustainable low-input grass-legume 
mixtures are increasingly preferred in conventional (non-organic) temporary grassland systems and in organic agriculture, where they constitute the basis for maintaining soil fertility and production of ruminant fodder.

Multi-species grasslands with grasses, forage legumes and forage herbs have attracted increasing attention (Smidt and Brimer 2005). However, they are hardly used in temporary grasslands that are cultivated between 2 and 4 years in Northern European fodder production systems. In addition to grasses and legumes, multi-species grassland mixtures can comprise dicotyledonous non-leguminous plant species (i.e., herbs) that either grow naturally in grasslands (Foster 1988) or are added to temporary grassland mixtures (Smidt and Brimer 2005). A number of herbs have the potential to increase fodder quality in grasslands due to high mineral contents (Belesky et al. 2001; Garcia-Ciudad et al. 1997; Høgh-Jensen et al. 2006; Pirhofer-Walzl et al. 2011; Sanderson et al. 2003) and high palatability (Søegaard et al. 2008). Further, increasing plant diversity in grasslands was shown to improve productivity (Frankow-Lindberg et al. 2009; Kirwan et al. 2007; Picasso et al. 2008; Tilman et al. 1997), resilience to environmental stress (Sanderson et al. 2005; Skinner 2008; Tilman and Downing 1994) and nutrient use (Tilman et al. 2002). Rising productivity with increasing the number of plant species in grassland experiments is on the one hand explained by niche complementarity among different plant species grown in a mixture (Hector et al. 1999; Tilman et al. 2002) and on the other hand by the increased chance of having a productive plant species in plots with high plant diversity ("sampling effect") (Huston 1997). Yet the "sampling effect" may be strong in the first years after grassland establishment while niche complementarity dominated in older grasslands (Tilman et al. 2002).

Nitrogen $(\mathrm{N})$ is the main limiting nutrient for plant growth in agricultural grassland systems (Whitehead 1995). Therefore, symbiotic $\mathrm{N}_{2}$ fixation of legumes is widely used to improve the $\mathrm{N}$ supply of the systems. Besides satisfying their own $\mathrm{N}$ needs, legumes can facilitate $\mathrm{N}$ acquisition of neighbouring plant species. Studies showed that $\mathrm{N}$ is relocated from legumes to grasses during the growing season (Høgh-Jensen and Schjoerring 1997; Høgh-Jensen and Schjoerring 2000; Rasmussen et al. 2007; Ta and Faris 1987). However, $\mathrm{N}$ is also relocated from grasses to legumes (Gylfadottir et al. 2007; Rasmussen et al. 2007; Tomm et al. 1994), which shows that below-ground $\mathrm{N}$ transfer is a bi-directional dynamic process. This process may partly occur because plants lose different $\mathrm{N}$ compounds from above- and below-ground plant tissue into the soil, for example by root exudation, dying roots and leaf leachates (Dahlin and Stenberg 2010; Hertenberger and Wanek 2004; Paynel et al. 2008; Wichern et al. 2008). This plant-derived belowground $\mathrm{N}$ can be taken up again by the plant that lost it or relocated to neighbouring plants over different pathways (Høgh-Jensen 2006; Paynel et al. 2008). N can be relocated from plant to plant directly by rootroot contacts or arbuscular mycorrhizal fungi that often connect roots of different plant species (He et al. 2003; Moyer-Henry et al. 2006; van der Heijden and Horton 2009) or indirectly over immobilizationmineralization processes.

Høgh-Jensen et al. (2006) showed in a three-species grass-legume-herb mixture that towards the end of the growing season approximately $6 \%$ of $\mathrm{N}$ in chicory and almost three times as much in perennial ryegrass derived from lucerne while the exchange of $\mathrm{N}$ between the two non-leguminous plant species, chicory and perennial ryegrass, was small. However, there is as yet little information about the potential contribution from different forage legumes on the $\mathrm{N}$ nutrition of neighbouring plant species in grass-legume-herb mixtures with more than three different plant species.

The objective of this study was to quantify the below-ground $\mathrm{N}$ transfer from forage legumes to neighbouring plants in temporary multi-species grassland mixtures grown for fodder production and comprising three functional groups: grasses, forage legumes and forage herbs.

We hypothesized 1) that species of forage legumes differ in their ability to donate $\mathrm{N}$ to neighbouring receiver plants, 2) that receiver plant species differ in their ability to receive below-ground $\mathrm{N}$ from donor legumes, and 3) that slurry application affects the below-ground $\mathrm{N}$ transfer mainly due to changes in the botanical composition of the grassland.

\section{Materials and methods}

Experimental site and grassland mixture

In June 2006 and April 2007 multi-species grasslands were established in an experimental crop rotation for 
dairy cows at the Research Farm Foulumgaard, Aarhus University, in the central part of Jutland, Denmark $\left(9^{\circ} 344^{\prime} 59\right.$ E, 56 $\left.6^{\circ} 29^{\prime} 22 \mathrm{~N}\right)$. The site has been managed under EU organic standards since 1987 with a six-year crop rotation including spring barley (Hordeum vulgare L.) - first year grassland - second year grassland - spring barley wholecrop - oat (Avena sativa L.) - maize (Zea mays L.). The multi-species mixtures were undersown in spring barley that was harvested in August 2006 and 2007, and the N transfer experiment was carried out in the growing season of 2008. In 2007 the multi-species mixture was harvested four times for silage. The loamy sandy soil, a typical Hapludult (Soil Survey Staff 1998) was developed on moraine material from the Weichselian glacial age. It had a $\mathrm{pH}$ value of 5.9 and contained $7.7 \%$ clay, $10 \%$ silt, $48 \%$ fine sand, $33 \%$ coarse sand, $1.6 \%$ carbon, $60 \mathrm{mg} \mathrm{kg}^{-1}$ exchangeable $\mathrm{K}$ and $21 \mathrm{mg} \mathrm{kg}^{-1}$ extractable $\mathrm{P}$ in the top $15 \mathrm{~cm}$. Precipitation and temperature for the growing season 2008 and a 30 year average were measured at a climate station close to the experimental plots of this study (Fig. 1a and b). Monthly mean temperatures from May to October in 2008 followed the 30 year average, while the precipitation in 2008 was considerably lower in May and greater in August and October compared with the 30 year average.

The multi-species grassland mixtures comprised two grasses, Festulolium (xFestulolium Perun with Lolium multiflorum Lam. and Festuca pratensis Huds. as parents: $31 \%$ of the total seed weight) and perennial ryegrass (Lolium perenne L.: $28 \%$ ), sown with a seeding rate of $59 \%$ total weight, five legumes, white clover (Trifolium repens L.: 5\%), red clover (Trifolium pratense L. cv. Rajah: 1\%), lucerne (Medicago sativa L. cv. Pondus: 15\%), birdsfoot trefoil (Lotus corniculatus L. cv. Lotanova: 2\%) and sainfoin (Onobrychis viciifolia L.: $3 \%$, sown with a seeding rate of $26 \%$ total weight and five herbs, chicory (Cichorium intybus L. cv. Spadona: 3\%), plantain (Plantago lanceolata L.: 3\%), caraway (Carum carvi L. cv. Sylvia: 3\%), salad burnet (Sanguisorba minor L.: 3\%) and chervil (Anthriscus cerefolium L.: $3 \%$ ), sown with a seeding rate of $15 \%$ total weight. Chervil and sainfoin did not establish and were thus not considered in the experiment.

Experimental plots and fertilization treatment

To confine the area of $\mathrm{N}$ transfer we placed $64 \mathrm{PVC}$ cylinders ( $0.4 \mathrm{~m}$ height; $0.297 \mathrm{~m}$ internal diameter) on

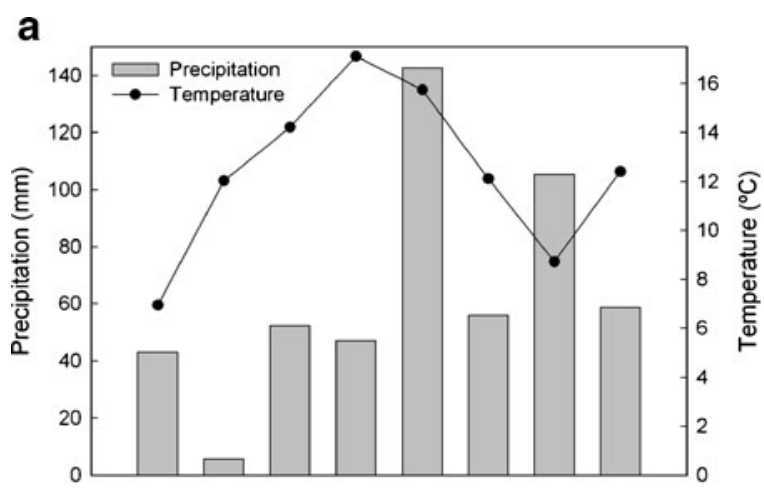

b

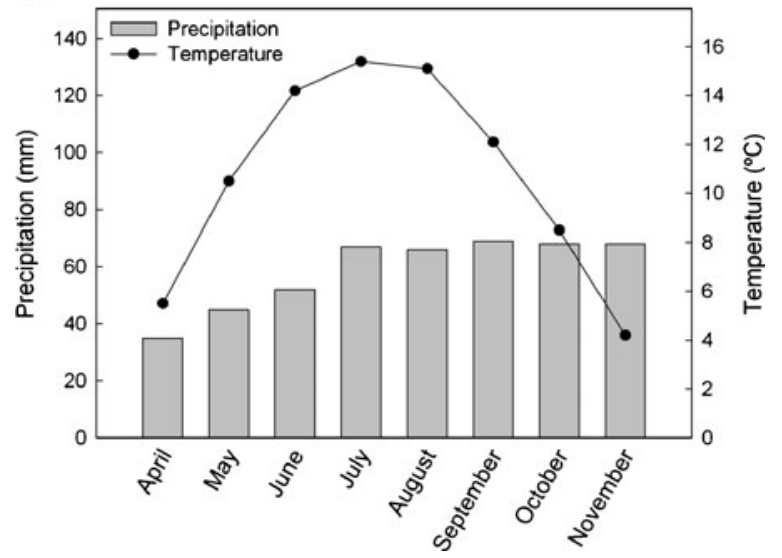

Fig. 1 Monthly rainfall and mean monthly temperature from April to November (a) in 2008 and (b) the 30 year average (1961-1990) measured next to the experimental field of the present study

15th of April 2008 with a shovel excavator approximately $0.35 \mathrm{~m}$ into the soil of the established multispecies mixture leaving approximately $0.05 \mathrm{~m}$ of the cylinder above-ground. Cylinders were positioned randomly in four blocks (two blocks with one and two blocks with 2 year old grasslands), however we had to ensure that white clover, red clover and lucerne plants are within the study area of each cylinder. To avoid cross contamination the minimum distance between cylinders was $0.5 \mathrm{~m}$. Four plots of each $2 \mathrm{~m}^{2}$ were used for determining $\mathrm{N}_{2}$ fixation in the legumes grown in the same multi-species mixture. Half of the cylinders and half of the plots for $\mathrm{N}_{2}$ fixation determination were supplied with cattle slurry (3.8\% dry matter) in amounts based on an analysis to provide $\mathrm{N}$ inputs equivalent to $2 \times 100 \mathrm{~kg} \mathrm{~N}$ ha $^{-1}$ (200 N plots). Fertilization treatments were $0 \mathrm{~N}$ and $200 \mathrm{~N}$. In $200 \mathrm{~N}$ plots, slurry was supplied at the 
onset of growth in the spring and after the first harvest. In addition to $\mathrm{N}\left(2 \times 60 \mathrm{~kg} \mathrm{NH}-\mathrm{N} \mathrm{ha}^{-1}\right)$, slurry application added $37 \mathrm{~kg} \mathrm{ha}^{-1} \mathrm{yr}^{-1}$ phosphorus (P) and $184 \mathrm{~kg} \mathrm{ha}^{-1} \mathrm{yr}^{-1}$ potassium (K). In $0 \mathrm{~N}$ plots no slurry was applied. Following the slurry application in $200 \mathrm{~N}$ plots, water was added to remove slurry from plant leaves. To avoid bias water was added to all plots $(0 \mathrm{~N}$ and $200 \mathrm{~N})$. To circumvent $\mathrm{K}$ deficiency, which was often reported at the experimental site (Askegaard et al. 2003), a K-rich organic fertilizer (vinasse, a byproduct from the sugar industry with 21\% K and 16\% sulphur) (Danish Plant Directorate 2010) was added to all plots.

\section{${ }^{15} \mathrm{~N}$ leaf-labelling to determine $\mathrm{N}$ transfer}

To trace $\mathrm{N}$ movement from white clover, red clover and lucerne (donor plants) to receiver plants we used the ${ }^{15} \mathrm{~N}$ leaf-labelling method, developed by Ledgard et al. (1985). Birdsfoot trefoil was not used as a donor because its proportion in the multi-species mixture was very small. The three donor legumes were labelled with ${ }^{15} \mathrm{~N}$ four times during the growing season and ${ }^{15} \mathrm{~N}$ enrichments of donor legumes and neighbouring receiver plants were measured at each of four harvests. For the leaf-labelling in one cylinder we placed one legume leaf from each of four legume plants in $2 \mathrm{ml}$ plastic vials containing $1 \mathrm{ml}$ of urea solution $(0.5 \% \mathrm{w} / \mathrm{v})$, enriched with 99 atom $\%{ }^{15} \mathrm{~N}$ (McNeill et al. 1997). White clover, red clover and lucerne were labelled separately in different cylinder. Each labelled legume had eight replicates. Vials were closed by sticky-tack without damaging leaf stems and left at least for 3 days to ensure sufficient ${ }^{15} \mathrm{~N}$ assimilation. After carefully removing the vials, leaves were dried with tissue to avoid contamination of surrounding plants or soil. Leaf-labelling was carried out approximately 2 weeks before each harvest, hence four times during the growing season (6th of May, 17th of June, 28th July and 15th September 2008). Depending on the number of legume donor plants in a cylinder the same or different plants were leaflabelled.

${ }^{15} \mathrm{~N}$-dilution method to determine legume $\mathrm{N}_{2}$-fixation

To determine symbiotic $\mathrm{N}_{2}$ fixation in legumes we used the ${ }^{15} \mathrm{~N}$-dilution method, described in details in
Peoples et al. (1989). Briefly, $4 \mathrm{~g}$ of ammoniumsulphate $\left(\left({ }^{15} \mathrm{NH}_{4}\right)_{2} \mathrm{SO}_{4}\right)$ enriched to 99.5 atom\% with ${ }^{15} \mathrm{~N}$ and $4 \mathrm{~g}$ of sugar were dissolved in de-ionized water and applied with an automatic pipette evenly on the soil surface of the $\mathrm{N}_{2}$ fixation plots on 18th of June 2008 (corresponding to $8 \mathrm{~kg} \mathrm{~N} \mathrm{ha}^{-1}$ ). Sugar was added to stimulate the immobilization process and consequently to promote a slow release of ${ }^{15} \mathrm{~N}$ during the growing season. Symbiotic $\mathrm{N}_{2}$ fixation in legumes was measured in the second, third and fourth harvest (2nd July, 22 August and 14th October 2008).

\section{Plant sampling}

Four times during the growing season (26th May, 2nd July, 22nd August and 14th October) above-ground plant tissue in the cylinders was harvested with an electric hand shear leaving a stubble of circa $0.05 \mathrm{~m}$. Lost plant parts in the cylinders were collected thoroughly to avoid soil ${ }^{15} \mathrm{~N}$ contamination by ${ }^{15} \mathrm{~N}$ enriched leaf parts. From the plots for $\mathrm{N}_{2}$ fixation determination an area of $0.6 \mathrm{~m} \times 0.6 \mathrm{~m}$ was harvested three times (2nd July, 22nd August and 14th October). To determine background ${ }^{15} \mathrm{~N}$ levels untreated plant species growing next to the treated plots in the same multi-species mixture were collected. We separated the multi-species mixture into different plant species, dried them at $80^{\circ} \mathrm{C}$ to constant dry weight and ground to fine powder in a Cyclotec 1093 sample mill (FOSS, Höganäs, Sweden). ${ }^{15} \mathrm{~N}$ enrichment and percentage total $\mathrm{N}$ in the different plant species from both, the $\mathrm{N}$ transfer experiment and $\mathrm{N}_{2}$ fixation study were analyzed on a ANCA-SL Elemental Analyzer coupled to a 20-20 Mass Spectrometer (SerCon Ltd., Crewe, UK) using the Dumas dry-combustion method.

\section{Calculations and statistical methods}

For the ${ }^{15} \mathrm{~N}$ transfer calculation we assumed that the donor legume $\mathrm{N}$ at the beginning of the growth period is the same as the ${ }^{15} \mathrm{~N}$ measured in the donor legume plus the ${ }^{15} \mathrm{~N}$ transferred to all receiver plant species at harvest time (denominator in the equation below). ${ }^{15} \mathrm{~N}$ transferred from legumes to neighbouring plants within one cylinder was estimated separately for each of the nine receiver species in each of the four harvests based on the equation in Ledgard et al. 
(1985) and modified accordingly to a multi-species system:

$\%$ Ndfd $=\frac{\left(N_{\text {receiver } 1-9} \times \%{ }^{15} N_{\text {receiver } 1-9}\right)}{\left(N_{\text {donor } 1-3} \times \%{ }^{15} N_{\text {donor } 1-3}\right)+\left(N_{\text {receiver } 1} \times \%{ }^{15} N_{\text {receiver } 1}\right)+\ldots\left(N_{\text {receiver } 9} \times \%{ }^{15} N_{\text {receiver } 9}\right)} \times 100$

The \%Ndfd is the proportion of $\mathrm{N}$ in receiver1-9 derived from donor1-3, $\mathrm{N}_{\text {donor1-3/receiver1-9 }}$ is the total amount of $\mathrm{N}$ measured in the respective receiver/ donor plant species. The $\%{ }^{15} \mathrm{~N}$ describes the enrichment of ${ }^{15} \mathrm{~N}$ in atom $\%$ measured in each donor/ receiver plant species minus the natural enrichment of ${ }^{15} \mathrm{~N}$ in atom $\%$ measured in plants grown in the same multi-species mixture adjacent to the cylinders. The $\% \mathrm{Ndfd}$ was subsequently multiplied by the shoot $\mathrm{N}$ accumulation of the respective receiver plant species to receive the amount of $\mathrm{N}$ transferred. To obtain the average \%Ndfd for individual plant species over the whole growing season proportions of $\mathrm{N}$ derived from the donor were divided by the total amount of shoot $\mathrm{N}$ accumulated in receiver plants in the whole growing season (weighted proportions).

The symbiotic $\mathrm{N}_{2}$ fixation in legumes was determined according to Peoples et al. (1989):

$\% N d f a=\left[1-\frac{\left(\%{ }^{15} N_{\text {legume }}-\%{ }^{15} N_{\text {nat.legume }}\right)}{\left(\%{ }^{15} N_{\text {reference }}-\%{ }^{15} N_{\text {nat.reference }}\right)}\right] \times 100$

The $\% \mathrm{Ndfa}$ is the proportion of $\mathrm{N}$ in the legume plant derived from the atmosphere, $\%{ }^{15} \mathrm{~N}_{\text {legume }}$ and ${ }^{15} \mathrm{~N}_{\text {reference }}$ is the enrichment of ${ }^{15} \mathrm{~N}$ in atom $\%$ measured in reference plant and legume, respectively and the $\%{ }^{15} \mathrm{~N}_{\text {nat.legume }}$ and $\%{ }^{15} \mathrm{~N}_{\text {nat.reference }}$ is the natural enrichment of ${ }^{15} \mathrm{~N}$ in atom\% measured in plants grown in the same multi-species mixture adjacent to the cylinders. The average ${ }^{15} \mathrm{~N}$ enrichment of all non-leguminous plant species in the multispecies mixture was used as reference value. The amount of $\mathrm{N}_{2}$ fixed was calculated by multiplying the proportion of Ndfa by the total amount of shoot $\mathrm{N}$ accumulated in the respective legume.

Herbage yield and $\mathrm{N}$ transfer in the multi-species mixture were analyzed statistically by analysis of variance with the open-source statistical program $R$ (R Development Core Team 2010). A four-way factorial ANOVA model was used to determine the effect of the four fixed factors, slurry application, donors, receivers and age on proportion $\mathrm{N}$ transfer, $\mathrm{N}$ accumulation and amount of $\mathrm{N}$ transferred. For homogeneity of residuals the square root was taken from $\mathrm{N}$ transfer response values. Furthermore, the effect of slurry application on percentage $\mathrm{N}_{2}$ fixation, $\mathrm{N}$ accumulation and amount of $\mathrm{N}_{2}$ fixed in the four legumes was tested by analysis of variance. Aboveground herbage yield from the cylinders was upscaled to receive herbage yields per hectare at the different harvests. Multiple comparisons of means for herbage yield were calculated using the WallerDuncan test.

\section{Results}

Herbage yield and $\mathrm{N}$ accumulation

Herbage yield during the growing season was relatively stable, with a higher yield at the second harvest $(p<0.05) .200 \mathrm{~N}$ plots had 28, 24, 13 and 6\% greater herbage yield than $0 \mathrm{~N}$ plots at the first, second, third and fourth harvest, respectively (Fig. 2). $\mathrm{N}$ accumulation of the multi-species mixture showed the same pattern as herbage yield, besides at the third harvest, when $\mathrm{N}$ accumulation in $0 \mathrm{~N}$ and $200 \mathrm{~N}$ plots were not different (Fig. 2b).

\section{Botanical composition}

Legumes dominated the multi-species mixture with 58 to $79 \%$ of total dry matter in $0 \mathrm{~N}$ plots and 46 to $77 \%$ in $200 \mathrm{~N}$ plots (Fig. 3). Red clover and lucerne had the greatest share among legumes while birdsfoot trefoil contributed only little to the herbage yield. Slurry application decreased the share of legumes in the herbage yield, mainly white clover, at the first and second harvests. In both, $0 \mathrm{~N}$ and $200 \mathrm{~N}$ plots, the lucerne proportion increased from the first to the third harvest and decreased again at the fourth harvest 


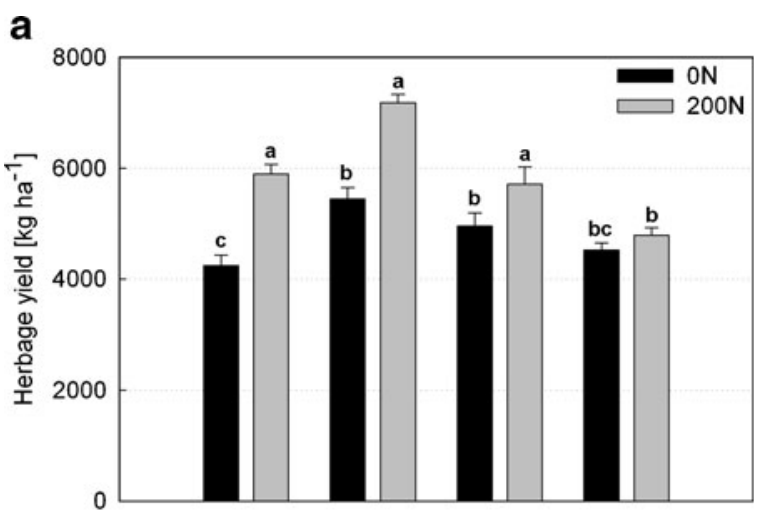

b

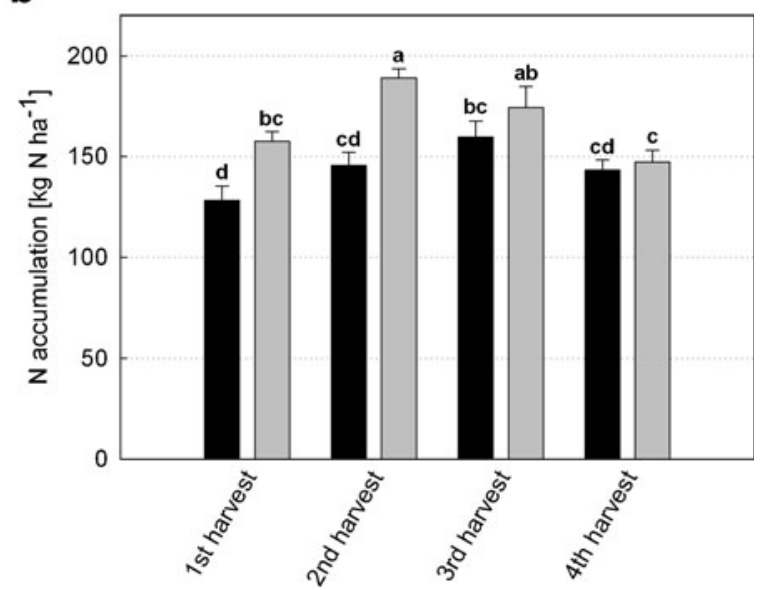

Fig. 2 Herbage yield (a) and $\mathrm{N}$ accumulation (b) of a grasslegume-herb mixture grown in PVC cylinders with two nitrogen levels $(0 \mathrm{~N}$ : no slurry application and $200 \mathrm{~N}$ : slurry according to $200 \mathrm{~kg} \mathrm{~N}$ ha-1) at 1st, 2nd, 3rd and 4th harvest in 2008. Different lower case letters show significant difference at the 0.05 level. Mean \pm SE $(n=8)$

(Fig. 3). Depending on the harvest, grasses comprised 7 to $24 \%$ of the herbage in $0 \mathrm{~N}$ plots and 16 to $41 \%$ in $200 \mathrm{~N}$ plots (Fig. 3). Slurry application stimulated the grass proportion at all harvests. Grasses decreased their proportion from the first to the third harvest and increased again at the fourth harvest, demonstrating an opposite pattern of temporal change during the growing season than the legumes. Herbs comprised 16 to $30 \%$ of total dry matter. Plantain had the greatest and chicory the second greatest proportion of herbs in $0 \mathrm{~N}$ and $200 \mathrm{~N}$ plots throughout the growing season. Caraway showed strong growth at the end of the growing season, while salad burnet was a very weak competitor at all four cuts. Slurry application slightly decreased the proportion of herbs in the multi-species mixture.
Symbiotic $\mathrm{N}_{2}$-fixation in legumes

All legumes in the cylinders derived most of their $\mathrm{N}$ from symbiotic $\mathrm{N}_{2}$ fixation, with birdsfoot trefoil in $200 \mathrm{~N}$ plots deriving the least and lucerne in $0 \mathrm{~N}$ plots the most (Fig. 4a). Both, $\mathrm{N}$ accumulation and amount of $\mathrm{N}_{2}$ fixed were significantly different among legumes $(p<0.0001$; Fig. $4 \mathrm{~b}$ and $c)$. Lucerne assimilated approximately $10 \mathrm{gN} \mathrm{m}^{-2}\left(100 \mathrm{~kg} \mathrm{~N} \mathrm{ha}^{-1}\right.$; Fig. 4b) in three harvests, which was around three times more than red clover and four times more than white clover. Because birdsfoot trefoil was only a minor proportion of total dry matter during the whole growing season $\mathrm{N}$ accumulation and hence, amount of $\mathrm{N}$ derived from $\mathrm{N}_{2}$ fixation in the plant was small. Slurry application decreased the proportion of $\mathrm{N}$ fixed symbiotically in all legumes $(p=0.02)$, except lucerne (Fig. 4a). Furthermore, $\mathrm{N}$ accumulation and amount of $\mathrm{N}_{2}$ fixed increased or was constant for red clover and lucerne and decreased for white clover and birdsfoot trefoil after slurry application $(p=0.002$; Fig. 4b). In three harvests the legumes in the multispecies herbage obtained approximately $17 \mathrm{gN} \mathrm{m}^{-2}$ $\left(170 \mathrm{~kg} \mathrm{~N} \mathrm{ha}^{-1}\right)$ in $0 \mathrm{~N}$ and $16 \mathrm{gN} \mathrm{m}^{-2}\left(160 \mathrm{~kg} \mathrm{~N} \mathrm{ha}^{-1}\right)$ in $200 \mathrm{~N}$ plots from symbiotic $\mathrm{N}_{2}$ fixation.

$\mathrm{N}$ transfer from legumes to neighbouring plants

$\mathrm{N}$ transfer was not affected by grassland age or by any factorial interactions including grassland age $(p>$ 0.05 ) and hence average $\mathrm{N}$ transfer data are presented. Legumes had different abilities to donate $\mathrm{N}$ to receiver plant species $(p<0.0001$, Table 1$)$. The proportions of $\mathrm{N}$ donated by the different donor legumes decreased from white clover, red clover to lucerne (Fig. 5a and b). The proportion of $\mathrm{N}$ in receiver plants derived from donor legumes was significantly different among receiver plants (Table 1) and ranged between 0.02 and 13.4\%. Generally, grasses received the greatest proportion of $\mathrm{N}$, chicory, plantain, red clover and caraway intermediate, white clover, lucerne and salad burnet low and birdsfoot trefoil only received very small proportions of $\mathrm{N}$ derived from the donor legumes (Fig. 5a and b). The pattern of the amount of $\mathrm{N}$ transfer in different receiver plant species was similar to the $\mathrm{N}$ transfer measured as proportion of $\mathrm{N}$ in the receiver plant. Yet red clover had high $\mathrm{N}$ contents (Fig. $5 \mathrm{c}$ and d) and hence relatively to the other receiver plant species 
Fig. 3 Botanical composition of a grass-legume-herb mixture grown in cylinders at no slurry application $(0 \mathrm{~N})$ and with slurry application $(200 \mathrm{~N})$ at $1 \mathrm{st}$, $2 \mathrm{nd}, 3 \mathrm{rd}$ and 4 th harvest in $2008(n=8)$

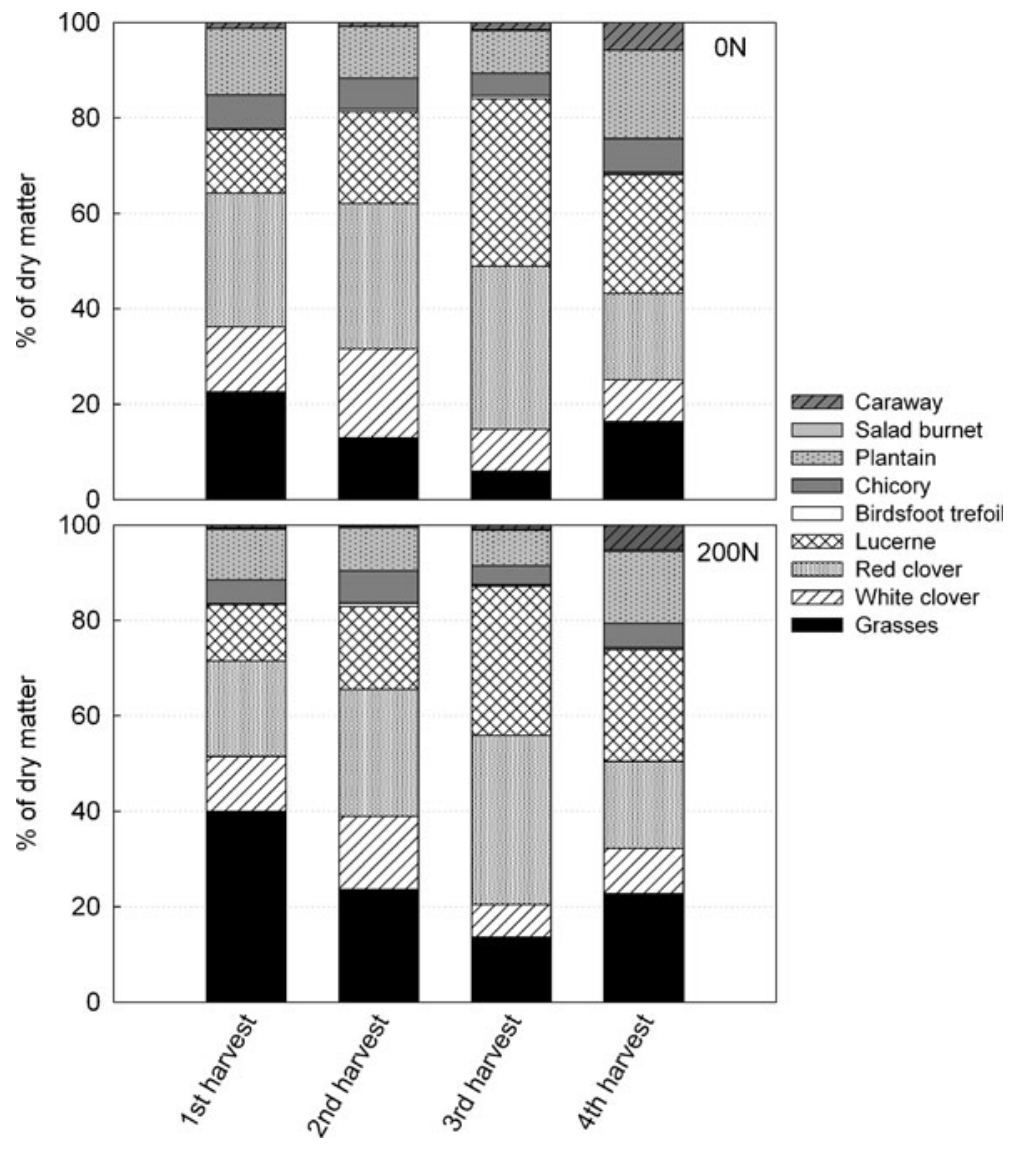

greater amounts than proportions of $\mathrm{N}$ transferred. On the other hand caraway and salad burnet showed relatively to the other receiver plants greater proportions than amounts of $\mathrm{N}$ derived mainly from white clover. The amount of $\mathrm{N}$ in individual receivers derived from all three donors during the growing season ranged between $0.005 \mathrm{gN} \mathrm{m}^{-2}\left(0.05 \mathrm{~kg} / \mathrm{ha}^{-1}\right)$ and $2.9 \mathrm{gN} \mathrm{m}^{-2}\left(29 \mathrm{~kg} \mathrm{ha}^{-1}\right)$ and $\mathrm{N}$ transferred to all receivers added up to approximately $30 \mathrm{~kg} \mathrm{~N} \mathrm{ha}^{-1}$ in $0 \mathrm{~N}$ and $51 \mathrm{~kg} \mathrm{~N} \mathrm{ha}^{-1}$ in $200 \mathrm{~N}$ plots.

Slurry application increased the $\mathrm{N}$ accumulation $(p<$ $0.01)$ and the amount of $\mathrm{N}$ transferred $(p<0.05$; Table 1). While the amount of $\mathrm{N}$ transferred during the whole growing season increased strongest in receiver grasses and intermediate in receiver red clover after slurry application it had only a small effect on the rest of the receiver plant species (Fig. 5). Hence, a significant slurry application $\mathrm{x}$ receiver interaction on $\%$ $\mathrm{N}$ transferred, $\mathrm{N}$ accumulation and amount of $\mathrm{N}$ transferred (Table 1) was mainly caused by a strong reaction of grasses to slurry application.

\section{Discussion}

The three donor legumes relocated $\mathrm{N}$ to all neighbouring receiver plant species, which confirms that mixtures in terms of $\mathrm{N}$ relocation are a very dynamic system (Tomm et al. 1994) and that legumes can contribute considerably to $\mathrm{N}$ nutrition of neighbouring plants in a growing season. Slurry application mainly stimulated grass growth and hence grass competitiveness in a multi-species mixture.

Lucerne, white clover and red clover's role as $\mathrm{N}$ suppliers

This study tested the hypothesis that different forage legumes differ in their ability to donate $\mathrm{N}$ to neighbouring plants.

The three donor legumes investigated in this study derived between $75 \%$ and $95 \%$ of their $\mathrm{N}$ from symbiotic $\mathrm{N}_{2}$ fixation, which is in agreement with other studies (Carlsson and Huss-Danell 2003) and 


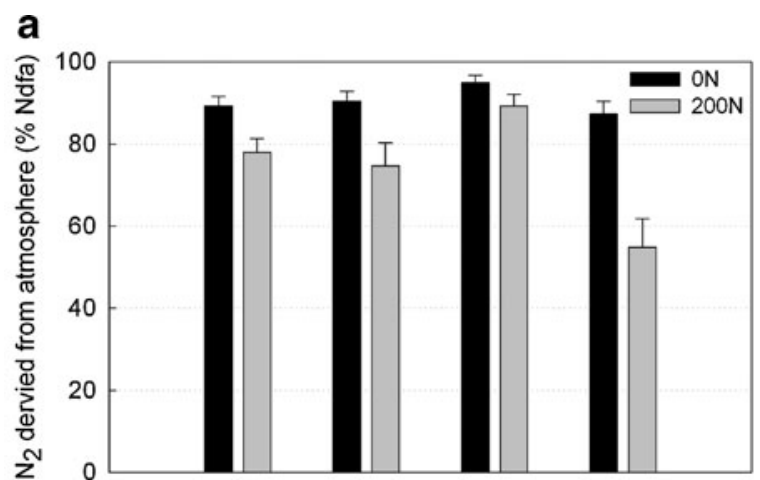

b
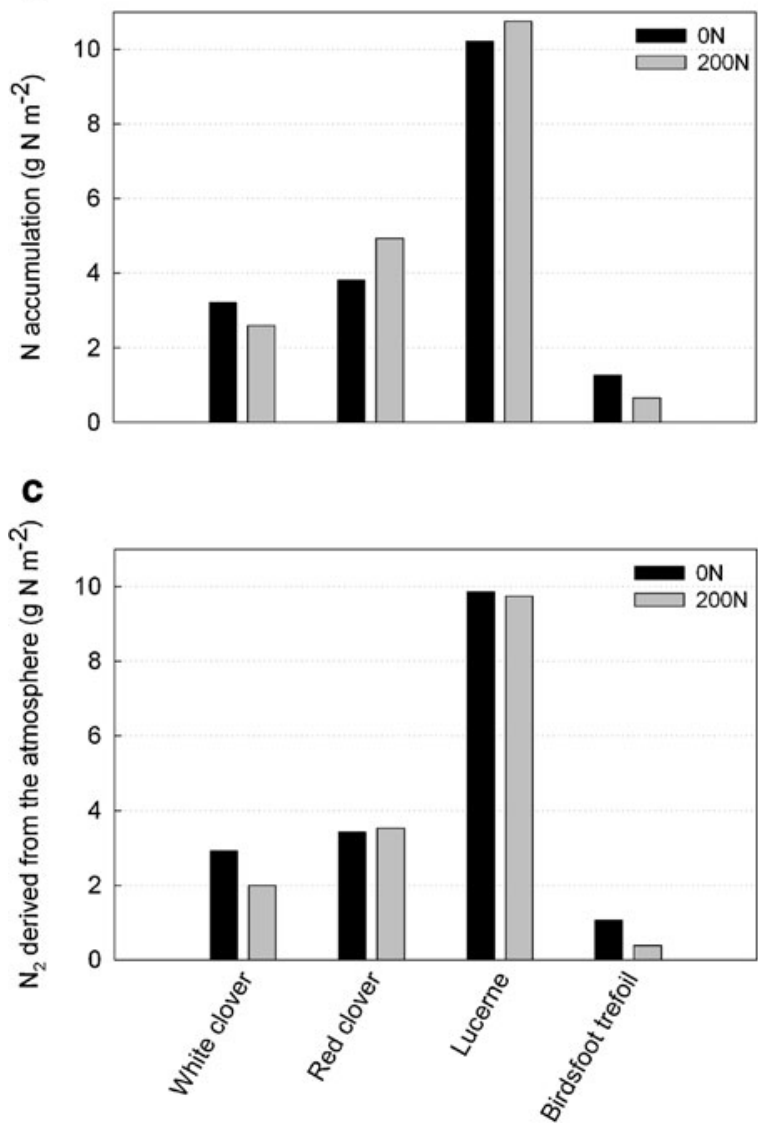

Fig. 4 Proportion $\mathrm{N}$ in the above-ground tissue of the four legumes derived from the atmosphere (Ndfa) (a), $\mathrm{N}$ accumulation in legume plants assimilated in the 2nd, 3rd and 4th harvest (b) and amount of $\mathrm{N}$ in the above-ground tissue of legumes fixed symbiotically (c) in plots with $(200 \mathrm{~N})$ and without $(0 \mathrm{~N})$ slurry application at the $2 \mathrm{nd}$, 3rd and 4th harvests in 2008. Values are means $\pm \mathrm{SE}(n=6)$

which positioned them as the potential N-rich donors in the multi-species mixture. The three donor legumes constituted on average $50 \%$ of the total herbage dry matter with decreasing proportions from red clover, lucerne to white clover (Fig. 2). As in previous studies (Carlsson and Huss-Danell 2003), lucerne derived more $\mathrm{N}$ from $\mathrm{N}_{2}$ fixation than red clover and white clover and its proportion of atmospheric $\mathrm{N}_{2}$ fixation did not decrease after slurry application compared to the other legumes. But to our surprise lucerne did not transfer much $\mathrm{N}$ to neighbouring plants. The fact that different plant species have different root architecture can be one explanation (Kutschera and Lichtenberger 1992). Lucerne forms a deep taproot with a small number of secondary roots (Kutschera and Lichtenberger 1992). This can hinder close root-root connections with neighbouring plants and hence explain the small $\mathrm{N}$ relocation from lucerne to neighbouring plant species in this study. Furthermore, our results suggested that lucerne had the ability to either keep its plant $\mathrm{N}$ content, which can be confirmed by only a small proportion of $\mathrm{N}$ rhizodeposition (Brophy and Heichel 1989; Wichern et al. 2008), or lucerne plants are able to re-uptake plant available $\mathrm{N}$ from the soil deposited by their own roots. Barber et al. (1996) confirm the first explanation by showing that lucerne plants accumulate $\mathrm{N}$ in their roots and thus use their roots as $\mathrm{N}$ reserve. This can be a strategy that ensures regrowth of lucerne plants after defoliation and may be a reason why lucerne roots release less $\mathrm{N}$ into the soil compared with white clover. Lucerne, however, contributed substantially to $\mathrm{N}$ content of neighbouring perennial ryegrass and chicory in a three-species mixture (Høgh-Jensen et al. 2006), which suggests that the type of mixture can affect the $\mathrm{N}$ transfer process.

White clover was the most efficient $\mathrm{N}$ donor species among the three legumes. This is in agreement with Høgh-Jensen and Schjoerring (2000), who found a greater yearly amount of $\mathrm{N}$ transfer from white clover to perennial ryegrass than from red clover to perennial ryegrass in binary mixtures over two growing seasons. White clover roots may lose more $\mathrm{N}$ compounds into the soil than lucerne and red clover roots because white clover perennates mainly through a stolon network (Frame 2005) and hence does not need to build up $\mathrm{N}$ reserves in roots for regrowth after defoliation. Further the turn-over of fine white clover roots can produce more rhizodeposits than lucerne and red clover.

Red clover derived the same proportion of $\mathrm{N}$ from $\mathrm{N}_{2}$ fixation as white clover, its proportion of total dry 
Table 1 Analysis of variance with main effects and interaction effects of different factors on annual $\mathrm{N}$ accumulation $(\mathrm{N}$ accum.), proportion $\mathrm{N}(\% \mathrm{~N}$ transfer) and amount of $\mathrm{N}(\mathrm{g} \mathrm{N}$ transfer) in the receiver plant species derived from the donor

legumes (Slurry application: $0 \mathrm{~N}$ and $200 \mathrm{~N}$, Donor: white clover, red clover and lucerne, Receiver: grasses, white clover, red clover, lucerne, birdsfoot trefoil, chicory, plantain, salad burnet and caraway)

\begin{tabular}{|c|c|c|c|c|}
\hline Factors & $\mathrm{DF}$ & $\mathrm{N}$ accum. & $\% \mathrm{~N}$ transfer & g N transfer \\
\hline Donor & 2 & NS & $* * *$ & $* * *$ \\
\hline Receiver & 8 & $* * *$ & $* * *$ & $* * *$ \\
\hline Slurry application & 1 & $* *$ & NS & $*$ \\
\hline Receiver x Donor & 13 & NS & $* * *$ & $* * *$ \\
\hline Slurry application $\mathrm{x}$ Donor & 2 & NS & NS & NS \\
\hline Slurry application $\mathrm{x}$ Receiver & 8 & $* * *$ & $* * *$ & $* * *$ \\
\hline Slurry application $\mathrm{x}$ Donor $\mathrm{x}$ Receiver & 12 & $* *$ & NS & NS \\
\hline Residuals & 983 & & & \\
\hline
\end{tabular}

Significance (Sign.): Not significant (NS): $p>0.05, *$ significance: $p<0.05, * *$ significance: $p<0.01, * * *$ significance: $p<0.001 . \mathrm{DF}=$ degrees of freedom

matter was high during the growing season and it accumulated most $\mathrm{N}$ of all plant species. Nevertheless, it donated only intermediate amounts of $\mathrm{N}$ to neighbouring plant species. As for lucerne, the taproot of red clover (Kutschera and Lichtenegger 1992) may cause difficulties for roots of receiver plants to get close enough to red clover roots to benefit from its below-ground $\mathrm{N}$. Furthermore, the large taproot and the inability of red clover to regrow through stolons after defoliation may suggest a similar $\mathrm{N}$ accumulation in red clover roots as was shown for lucerne roots (Barber et al. 1996).

Are different forage plant species different types of $\mathrm{N}$ receivers?

The current study tested the hypothesis that receiver plant species differ in their ability to take up belowground $\mathrm{N}$ from donor legumes. Our data confirmed this and thus suggested that competition for belowground $\mathrm{N}$ was asymmetric in this multi-species grassland, as different receiver plant species derived different proportions of their above-ground $\mathrm{N}$ from donor legumes (Table 1, Fig. 5). $\mathrm{N}$ transfer seemed to be related to $\mathrm{N}$ accumulation of the receiver plant species, which means that plants with large aboveground production were also strong competitors for below-ground $\mathrm{N}$ derived from neighbouring legumes. The two legumes, white clover and lucerne, did not follow that trend.

Grasses were strong receivers of $\mathrm{N}$ derived from neighbouring legumes. The fibrous root system of grasses (Kutschera and Lichtenegger 1982) strongly contributed to large root biomass and root surface with resulting high $\mathrm{N}$ uptake of grass-legume and grasslegume-herb mixtures (Braun et al. 2010). Earlier studies on $\mathrm{N}$ transfer also showed that grasses are very strong $\mathrm{N}$ competitors in two-species (Gylfadottir et al. 2007; Høgh-Jensen and Schjoerring 1997; Rasmussen et al. 2007) and three-species mixtures (Høgh-Jensen et al. 2006).

White clover, the legume that donated most $\mathrm{N}$ among the three legumes, was not a strong receiver of $\mathrm{N}$ from red clover or lucerne. Its small root system might not be able to reach soil $\mathrm{N}$ compounds deposited in the soil from donor legumes. The strong above-ground growth of lucerne and red clover suggested that they competed intensely for below ground $\mathrm{N}$. Yet forage legumes were shown to receive greater proportions of their $\mathrm{N}$ from atmospheric $\mathrm{N}_{2}$ fixation when grown in mixtures compared with monocultures (Carlsson and Huss-Danell 2003; Hardarson et al. 1988; Nyfeler et al. 2011). This may explain the large $\mathrm{N}_{2}$ fixation but generally low $\mathrm{N}$ acquisitions from the soil $\mathrm{N}$ pool for white clover and lucerne in this study. For that reason legumes affect neighbouring nonlegumes indirectly, simply by reduced competition for soil N. Lucerne and white clover were weak $\mathrm{N}$ receivers and hence fit well to this pattern, while red clover was a relatively strong competitor for donor legume $\mathrm{N}$ and consequently among the legumes acquired the greatest proportions and amounts of $\mathrm{N}$ from mainly white clover. 
Fig. 5 Weighted proportions of $\mathrm{N}$ in receiver plants derived from donor legumes (a and $\mathbf{b}), \mathrm{N}$ accumulation in receiver plant species for the different donors (c and d) and amount of $\mathrm{N}$ (e and f) in nine receiver plant species derived from white clover, red clover and lucerne, respectively in plots without ( $0 \mathrm{~N}$ : a, c and e) and with slurry application (200 N: b, d and f) during the growing season in 2008 . Intraspecific $\mathrm{N}$ transfer was not possible to measure; hence only two $\mathrm{N}$ transfer values $(\mathbf{a}, \mathbf{b}, \mathbf{e}, \mathbf{f})$ are presented for white clover, red clover and lucerne as receivers

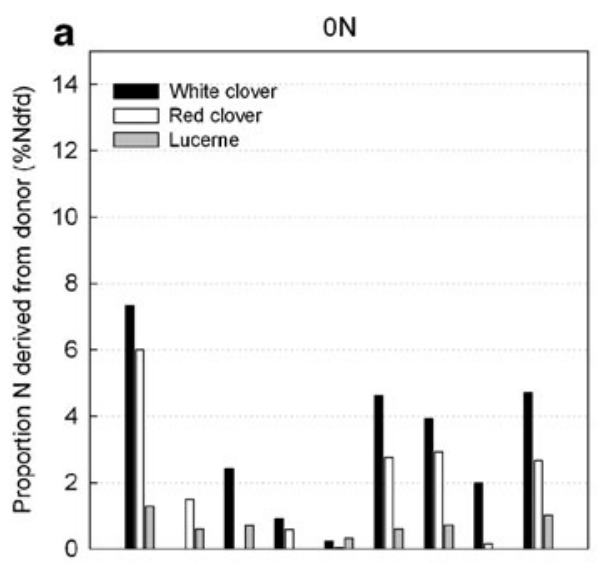

b $200 \mathrm{~N}$

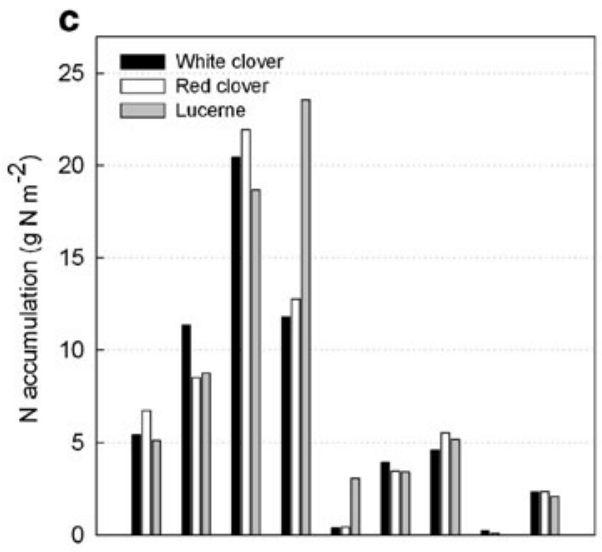

d

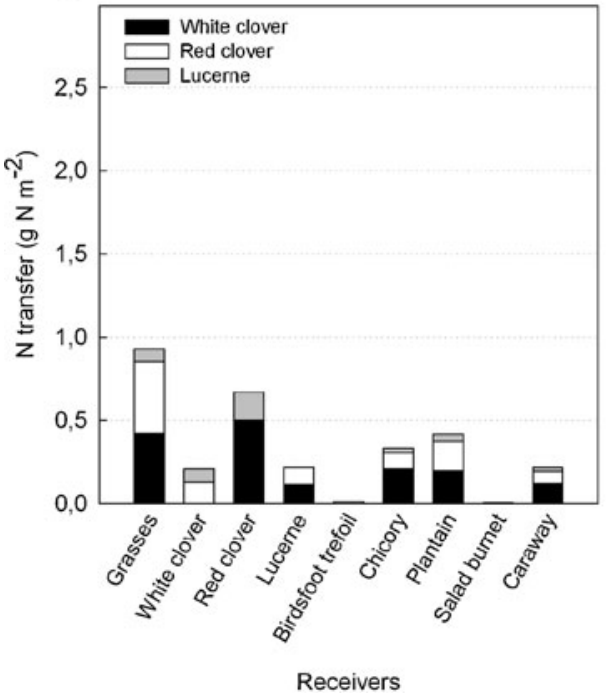

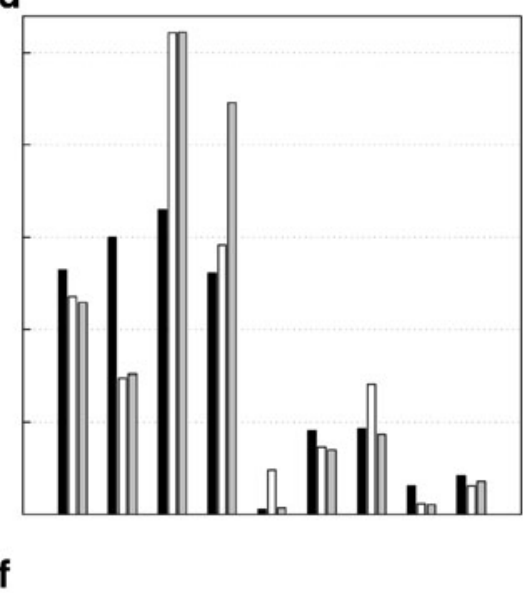
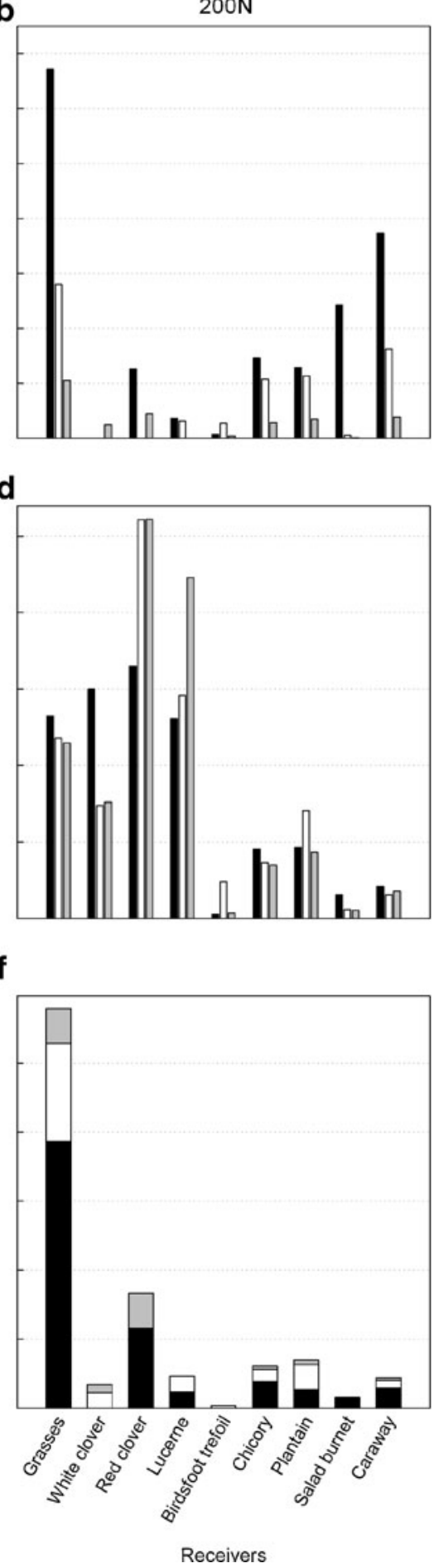

Herbs depend like grasses on $\mathrm{N}$ acquired from the soil $\mathrm{N}$ pool. Yet they derived smaller amounts of $\mathrm{N}$ from the donor legumes compared with grasses. This may be explained by their taproots, which increase their ability to derive $\mathrm{N}$ from deep soil layers, however might limit them to acquire $\mathrm{N}$ derived from donor legumes. Høgh-Jensen et al. (2006) also showed that in a three species grass-legume-herb 
mixture, chicory was a poorer $\mathrm{N}$ receiver than perennial ryegrass. Up to $6 \%$ of $\mathrm{N}$ in chicory in comparison with approximately $16 \%$ of $\mathrm{N}$ in grass was derived from a lucerne donor plant.

Plantain derived similar amounts of $\mathrm{N}$ from donor legumes as chicory, even though its proportion in the total herbage was greater than chicory. This suggests that plantain was not as competitive for $\mathrm{N}$ as chicory. Caraway received similar proportions of $\mathrm{N}$ from donor legumes as chicory and plantain. Nonetheless, this $\mathrm{N}$ transfer derives mainly from the fourth cut (data not shown) when the proportion of caraway dry matter was a significant part of the multi-species mixture (Fig. 3). This agrees with a Finnish field experiment where caraway did not only have large above-ground biomass but also greater root dry matter and root-shoot ratio than perennial grasses mainly in the end of the growing season (Hakala et al. 2009).

The contribution of birdsfoot trefoil and salad burnet to herbage yield was very small during to the whole growing season. Even though salad burnet received some below-ground $\mathrm{N}$ derived mainly from white clover, the amount of $\mathrm{N}$ transfer during the whole growing season was insignificant.

\section{Slurry effect on $\mathrm{N}$ donors, $\mathrm{N}$ receivers and $\mathrm{N}$ transfer}

The current study tested the hypothesis that fertilizer application in the form of slurry changes the botanical composition and influences below-ground $\mathrm{N}$ transfer. Slurry application stimulated grass growth and slightly suppressed legumes, but hardly changed the proportion of herbs. Slurry application seems to influence mainly the $\mathrm{N}$ relocated from legumes to grasses. After slurry application, grasses received four-fold more $\mathrm{N}$ from white clover, double amounts of $\mathrm{N}$ from lucerne and slightly increased amounts of $\mathrm{N}$ from red clover (Fig. 5), despite that the proportion of $\mathrm{N}_{2}$ derived from the atmosphere decreased in the donor legumes after slurry application. This is in agreement with Paynel et al. (2008) who showed a three-fold increase of $\mathrm{N}$ transfer from white clover to perennial ryegrass after nitrate application. Both Elgersma et al. (2000) and HøghJensen and Schjoerring (1997) also observed increased $\mathrm{N}$ transfer from legumes to grasses after mineral fertilizer and urea fertilizer application respectively, even though applied $\mathrm{N}$ in those studies was lower than the $200 \mathrm{~kg} \mathrm{~N} \mathrm{ha}^{-1}$ applied in this study. Furthermore, an increase in $\mathrm{N}$ transfer after nitrate application was positively correlated with root dry weight (Paynel et al. 2008), which supports the hypothesis that root characteristics of receiver plant species strongly determine $\mathrm{N}$ transfer. Increased root biomass of grasses which is favourable for $\mathrm{N}$ uptake can explain their superiority over herbs in this $\mathrm{N}$ transfer study.

Is it the $\mathrm{N}$ donor or $\mathrm{N}$ receiver that determines the quantity of below-ground $\mathrm{N}$ transfer?

This study suggests that below-ground $\mathrm{N}$ transfer depends on both the $\mathrm{N}$ donor and $\mathrm{N}$ receiver. Grasslegume-herb mixtures comprise different plant species with different types of root architecture (Braun et al. 2010). Since it is suggested that relative root growth rate, root biomass, fine root density and total root surface area play an important role in below-ground resource competition (Aerts et al. 1991; Casper and Jackson 1997), root architecture may facilitate or impair $\mathrm{N}$ transfer. Mommer et al. (2010) showed that roots of plant species grown in a multi-species mixture formed more clumps than in monocultures. Roots in closer contact with each other would ease below-ground $\mathrm{N}$ transfer and consequently belowground $\mathrm{N}$ transfer can be greater in mixtures compared with monocultures.

$\mathrm{N}$ transfer is also likely to be influenced by various types of pathways for $\mathrm{N}$ transfer (Høgh-Jensen 2006; Paynel et al. 2008), which were not determined in this study. The contribution of arbuscular mycorrhizal fungi on direct $\mathrm{N}$ transfer is still unclear (Smith and Read 2008). However different capacities of plant species in forming mycorrhizal symbioses may produce different types of $\mathrm{N}$ donors and $\mathrm{N}$ receivers. Therefore, $\mathrm{N}$ transfer can be stimulated by a careful selection of forage plant species and mycorrhizal fungi (Mårtensson et al. 1998).

\section{Methodological reflections}

The present $\mathrm{N}$ transfer experiment was confined to cylinders placed $0.35 \mathrm{~m}$ deep in the soil, which could have affected growth conditions of the multi-species grassland. However, large experimental plots with the same multi-species grassland grown adjacent to the cylinders showed similar yearly herbage yields and botanical composition (Søegaard et al. 2008) to results presented for the grassland grown in cylinders in this study. 
To trace $\mathrm{N}$ transfer from legumes to neighbouring plants we chose to start ${ }^{15} \mathrm{~N}$ labelling and hence $\mathrm{N}$ transfer observations 2 weeks before grassland harvests, a time period long enough for the ${ }^{15} \mathrm{~N}$ to distribute over different plant parts (Palta et al. 1991). A multiple ${ }^{15} \mathrm{~N}$ pulse-labelling was applied to produce a continuous ${ }^{15} \mathrm{~N}$ enriched plant-soil system. When using the ${ }^{15} \mathrm{~N}$ leaf-labelling method we assume that 1) the ${ }^{15} \mathrm{~N}$ absorbed by the donor plant is equally distributed to all plant parts that contribute to $\mathrm{N}$ transfer and 2) the donor plant species is constantly enriched with ${ }^{15} \mathrm{~N}$ over the observation period. Both assumptions were thoroughly discussed in Høgh-Jensen and Schjoerring (2000).

$\mathrm{N}$ transfer in this study was assessed from ${ }^{15} \mathrm{~N}$ proportions only in above-ground plant parts. Plant species, however, may allocate transferred $\mathrm{N}$ differently to below-ground plant parts which can result in an over- or underestimation of $\mathrm{N}$ transfer and hence can have affected differences in $\mathrm{N}$ receiver plants. Further studies are needed to determine the magnitude of this effect.

\section{Conclusions}

This study showed that white clover and grasses, which are a traditional forage mixture for temperate European grasslands (Moore 2003), match very well in terms of sustainable $\mathrm{N}$ use. Other $\mathrm{N}$ transfer studies on binary mixtures including white clover and perennial ryegrass confirm the strong link between those two plant species (Høgh-Jensen and Schjoerring 2000; Paynel et al. 2008), and Rasmussen et al. (2007) found in a Danish grassland up to $40 \%$ of grass $\mathrm{N}$ content derived from white clover. These large $\mathrm{N}$ exchanges between white clover and grasses, which in this study comprised perennial ryegrass and festulolium, seem not to have changed after adding several other forage plant species to the mixture. Yet the grasses contained smaller proportions of $\mathrm{N}$ derived from white clover compared with studies on binary mixtures. This implies that grasses had to share below-ground $\mathrm{N}$ derived from the legumes with neighbouring plants but were, especially after slurry application, the strongest competitors for $\mathrm{N}$.

This study also showed that different root architecture and plant regrowth strategies may partly explain varying abilities of plant species to receive and donate N. The growth of plant species in a grassland mixture can be improved if $\mathrm{N}$ transfer and hence the use of $\mathrm{N}$ derived from symbiotic $\mathrm{N}_{2}$ fixation is increased. However, more knowledge on below-ground $\mathrm{N}$ transfer pathways and their relation to root architecture of plant species grown in a mixture is needed before we are able to suggest multi-species grassland mixtures that facilitate $\mathrm{N}$ transfer.

Acknowledgments We would like to thank Anja Hecht-Ivø for help with $\mathrm{N}$ and ${ }^{15} \mathrm{~N}$ analyses and the workers from the Research Farm Foulumgaard for practical support. We are also grateful to the International Centre for Research in Organic Food Systems (ICROFS) who funded the project.

\section{References}

Aerts R, Boot RGA, Vanderaart PJM (1991) The relation between aboveground and belowground biomass allocation patterns and competitive ability. Oecologia 87:551-559

Askegaard M, Eriksen J, Olesen JE (2003) Exchangeable potassium and potassium balances in organic crop rotations on a coarse sand. Soil Use Manag 19:96-103

Barber LD, Joern BC, Volenec JJ, Cunningham SM (1996) Supplemental nitrogen effects on alfalfa regrowth and nitrogen mobilization from roots. Crop Sci 36:1217-1223

Belesky DP, Turner KE, Fedders JM, Ruckle JM (2001) Mineral composition of swards containing forage chicory. Agron J 93:468-475

Braun M, Schmid H, Grundler T, Hulsbergen KJ (2010) Rootand-shoot growth and yield of different grass-clover mixtures. Plant Biosyst 144:414-419

Brophy LS, Heichel GH (1989) Nitrogen release from roots of alfalfa and soybean grown in sand culture. Plant and Soil $116: 77-84$

Carlsson G, Huss-Danell K (2003) Nitrogen fixation in perennial forage legumes in the field. Plant and Soil 253:353-372

Casper BB, Jackson RB (1997) Plant competition underground. Annu Rev Ecol Syst 28:545-570

Dahlin AS, Stenberg M (2010) Transfer of N from red clover to perennial ryegrass in mixed stands under different cutting strategies. Eur J Agron 33:149-156

Danish Plant Directorate (2010) Vejledning om økologisk jordbrugsporduktion (Guideline for organic agricultural production). http://pdir.fvm.dk/Vejledning_om_oekologisk_ jordbrugsproduktion.aspx?ID $=2137$

R Development Core Team (2010) R: A language and environment for statistical computing. http://www.R-project.org

Elgersma A, Schlepers H, Nassiri M (2000) Interactions between perennial ryegrass (Lolium perenne L.) and white clover (Trifolium repens L.) under contrasting nitrogen availability: productivity, seasonal patterns of species composition, $\mathrm{N}-2$ fixation, $\mathrm{N}$ transfer and $\mathrm{N}$ recovery. Plant and Soil 221:281-299 
Foster L (1988) Herbs in pastures - development and research in Britain, 1850-1984. Biol Agric Hortic 5:97-133

Frame J (2005) Forage legumes for temperate grasslands. Science Publishers, Inc., Enfield

Frankow-Lindberg BE, Brophy C, Collins RP, Connolly J (2009) Biodiversity effects on yield and unsown species invasion in a temperate forage ecosystem. Ann Bot 103:913-921

Fred EB, Baldwin IL, McCoy E (1932) Root nodule bacteria and leguminous plants. University of Wisconsin, Studies in Science 52:5

Garcia-Ciudad A, Ruano-Ramos A, deAldana BRV, Garcia-Criado B (1997) Interannual variations of nutrient concentrations in botanical fractions from extensively managed grasslands. Anim Feed Sci Technol 66:257-269

Gylfadottir T, Helgadottir A, Høgh-Jensen H (2007) Consequences of including adapted white clover in northern European grassland: transfer and deposition of nitrogen. Plant and Soil 297:93-104

Hakala K, Keskitalo M, Eriksson C, Pitkanen T (2009) Nutrient uptake and biomass accumulation for eleven different field crops. Agric Food Sci 18:366-387

Hardarson G, Danso SKA, Zapata F (1988) Dinitrogen fixation measurements in alfalfa-ryegrass swards using N-15 and influence of the reference crop. Crop Sci 28:101-105

He XH, Critchley C, Bledsoe C (2003) Nitrogen transfer within and between plants through common mycorrhizal networks (CMNs). Crit Rev Plant Sci 22:531-567

Hector A, Schmid B, Beierkuhnlein C, Caldeira MC, Diemer M, Dimitrakopoulos PG, Finn JA, Freitas H, Giller PS, Good J, Harris R, Hogberg P, Huss-Danell K, Joshi J, Jumpponen A, Korner C, Leadley PW, Loreau M, Minns A, Mulder CPH, O'Donovan G, Otway SJ, Pereira JS, Prinz A, Read DJ, Scherer-Lorenzen M, Schulze ED, Siamantziouras ASD, Spehn EM, Terry AC, Troumbis AY, Woodward FI, Yachi S, Lawton JH (1999) Plant diversity and productivity experiments in European grasslands. Science 286:1123-1127

Hertenberger G, Wanek W (2004) Evaluation of methods to measure differential N-15 labeling of soil and root N pools for studies of root exudation. Rapid Commun Mass Spectrom 18:2415-2425

Høgh-Jensen H (2006) The nitrogen transfer between plants: an important but difficult flux to quantify. Plant and Soil 282:1-5

Høgh-Jensen H, Schjoerring JK (1997) Interactions between white clover and ryegrass under contrasting nitrogen availability: N-2 fixation, $\mathrm{N}$ fertilizer recovery, $\mathrm{N}$ transfer and water use efficiency. Plant and Soil 197:187-199

Høgh-Jensen H, Schjoerring JK (2000) Below-ground nitrogen transfer between different grassland species: direct quantification by $\mathrm{N}-15$ leaf feeding compared with indirect dilution of soil N-15. Plant and Soil 227:171-183

Høgh-Jensen H, Nielsen B, Thamsborg SM (2006) Productivity and quality, competition and facilitation of chicory in ryegrass/legume-based pastures under various nitrogen supply levels. Eur J Agron 24:247-256

Huston MA (1997) Hidden treatments in ecological experiments: re-evaluating the ecosystem function of biodiversity. Oecologia 110:449-460

Kirwan L, Luescher A, Sebastia MT, Finn JA, Collins RP, Porqueddu C, Helgadottir A, Baadshaug OH, Brophy C,
Coran C, Dalmannsdottir S, Delgado I, Elgersma A, Fothergill M, Frankow-Lindberg BE, Golinski P, Grieu P, Gustavsson AM, Hoglind M, Huguenin-Elie O, Iliadis C, Jorgensen M, Kadziuliene Z, Karyotis T, Lunnan T, Malengier M, Maltoni S, Meyer V, Nyfeler D, NykanenKurki P, Parente J, Smit HJ, Thumm U, Connolly J (2007) Evenness drives consistent diversity effects in intensive grassland systems across 28 European sites. J Ecol 95:530-539

Kutschera L, Lichtenegger E (1982) Wurzelatlas mitteleuropäischer Grünlandpflanzen. Band 1, Monocotyldoneae. Gustav Fischer Verlag, Stuttgart

Kutschera L, Lichtenegger E (1992) Wurzelatlas mitteleuropäischer Grünlandpflanzen, Bd. 2: Pteridophyta und Dicotyledoneae (Magnoliopsida). Gustav Fischer Verlag, Stuttgart

Ledgard SF, Freney JR, Simpson JR (1985) Assessing nitrogen transfer from legumes to associated grasses. Soil Biol Biochem 17:575-577

Lewis B, Schrire B, Mackinder B, Lock M (2005) Legumes of the world. Kew Publishing, Surrey

Mårtensson AM, Rydberg I, Vestberg M (1998) Potential to improve transfer of $\mathrm{N}$ in intercropped systems by optimizing host-endophyte combinations. Plant and Soil 205:57-66

McNeill AM, Zhu CY, Fillery IRP (1997) Use of in situ N-15labeling to estimate the total below-ground nitrogen of pasture legumes in intact soil-plant systems. Aust J Agric Res 48:295-304

Mommer L, van Ruijven J, de Caluwe H, Smit-Tiekstra AE, Wagemaker CAM, Ouborg NJ, Bogemann GM, van der Weerden GM, Berendse F, de Kroon H (2010) Unveiling below-ground species abundance in a biodiversity experiment: a test of vertical niche differentiation among grassland species. J Ecol 98:1117-1127

Moore KJ (2003) Compendium of common forages. In: Barnes RF, Nelson CJ, Collins M, Moore KJ (eds) Forages: an introduction to grassland agriculture, 6th edn. Iowa State University Press, Iowa, pp 237-238

Moyer-Henry KA, Burton JW, Israel D, Rufty T (2006) Nitrogen transfer between plants: a N-15 natural abundance study with crop and weed species. Plant and Soil 282:7-20

Nyfeler D, Huguenin-Elie O, Matthias S, Frossard E, Luscher A (2011) Grass-legume mixtures can yield more nitrogen than legume pure stands due to mutual stimulation of nitrogen uptake from symbiotic and non-symbiotic sources. Agric Ecosyst Environ 140:155-163

Palta JA, Fillery IR, Mathews EL, Turner NC (1991) Leaf feeding of [N-15]Urea for labeling wheat with nitrogen. Aust J Plant Physiol 18:627-636

Paynel F, Lesuffleur F, Bigot J, Diquelou S, Cliquet JB (2008) A study of N-15 transfer between legumes and grasses. Agron Sustain Dev 28:281-290

Peoples MB, Faizah AW, Rerkasem B and Herridge DF (1989) Methods for evaluating nitrogen fixation by nodulated legumes in the field. Australian Centre for International Agricultural Research, Canberra

Picasso VD, Brummer EC, Liebman M, Dixon PM, Wilsey BJ (2008) Crop species diversity affects productivity and weed suppression in perennial polycultures under two management strategies. Crop Sci 48:331-342 
Pirhofer-Walzl K, Søegaard K, Høgh-Jensen H, Eriksen J, Sanderson MA, Rasmussen J, Rasmussen J (2011) Forage herbs improve mineral composition of grassland herbage (in press)

Rasmussen J, Eriksen J, Jensen ES, Esbensen KH, HøghJensen H (2007) In situ carbon and nitrogen dynamics in ryegrass-clover mixtures: transfers, deposition and leaching. Soil Biol Biochem 39:804-815

Sanderson MA, Labreveux M, Hall MH, Elwinger GF (2003) Nutritive value of chicory and English plantain forage. Crop Sci 43:1797-1804

Sanderson MA, Soder KJ, Muller LD, Klement KD, Skinner RH, Goslee SC (2005) Forage mixture productivity and botanical composition in pastures grazed by dairy cattle. Agron J 97:1465-1471

Skinner RH (2008) Yield, root growth, and soil water content in drought-stressed pasture mixtures containing chicory. Crop Sci 48:380-388

Smidt NW, Brimer L (2005) The use of herbs in pastures: an interview survey among bio-dynamic and organic farmers with dairy cattle. Agric Hum Values 22:355-363

Smith S, Read D (2008) Mycorrhizal symbiosis. Academic, San Diego

Søegaard K, Eriksen J, Askegaard M (2008) Herbs in grasslands - effect of slurry and grazing/cutting on species composition and nutritive value. In: Hopkins A, Gustafsson T, Bertilsson J, Dalin G, Nilsdotter-Linde N, Spörndly E (eds) Biodiversity and animal feed, 13th edn. Uppsala, Sweden, pp 200-202
Soil Survey Staff (1998) Ultisols. In: Soil Survey Staff (ed) Keys to soil taxonomy. United States Department of Agriculture, Natural Resources Conservation Service, Washington, pp 267-269

Ta TC, Faris MA (1987) Species variation in the fixation and transfer of nitrogen from legumes to associated grasses. Plant and Soil 98:265-274

Tilman D, Downing JA (1994) Biodiversity and stability in grasslands. Nature 367:363-365

Tilman D, Knops J, Wedin D, Reich P, Ritchie M, Siemann E (1997) The influence of functional diversity and composition on ecosystem processes. Science 277:1300-1302

Tilman D, Knops J, Wedin D, Reich P (2002) Plant diversity and composition: effects on productivity and nutrient dynamics of experimental grasslands. In: Loreau M, Naeem S, Inchausti P (eds) Biodiversity and ecosytem functioning: synthesis and perspectives, 1st edn. Oxford University Press, Oxford, pp 21-35

Tomm GO, Vankessel C, Slinkard AE (1994) Bidirectional transfer of nitrogen between alfalfa and bromegrass - Short and long-term evidence. Plant and Soil 164:77-86

van der Heijden MGA, Horton TR (2009) Socialism in soil? The importance of mycorrhizal fungal networks for facilitation in natural ecosystems. J Ecol 97:1139-1150

Whitehead DC (1995) Grassland nitrogen. CABI Publishing, Wallingford

Wichern F, Eberhardt E, Mayer J, Joergensen RG, Muller T (2008) Nitrogen rhizodeposition in agricultural crops: methods, estimates and future prospects. Soil Biol Biochem 40:30-48 